with mercury tubes, assuming that the resistance of 1 metre of mercury is 0.95352 B.A. units, is given in the accompanying table:

\begin{tabular}{|c|c|c|c|}
\hline Coil. & 1888 (R. T. G.). & 1908 (F. E. S.). & 1932 (Hartshorn). \\
\hline D & 1.00013 & 1.00012 & 1.00011 \\
E & 1.00073 & 1.00072 & 1.00071 \\
\hline
\end{tabular}

The coils have been very carefully intercompared this year at the National Physical Laboratory and their value determined in terms of the international ohm by Dr. Hartshorn. The international ohm is defined as the resistance at $0^{\circ} \mathrm{C}$. of a column of mercury $106 \cdot 300 \mathrm{~cm}$. in length and $1 \mathrm{sq} . \mathrm{mm}$. in cross section. Tables are given illustrating how the values found for the coils during the last sixty-five years have varied. These show that considerable variations appeared prior to 1888. These depend probably on errors arising in the temperature determinations of ' $\mathrm{D}$ ' and ' $\mathrm{E}$ ', as an uncertainty in the temperature of these coils of $0.1^{\circ} \mathrm{C}$. implies an uncertainty of 0.0003 B.A. units in the resistance measurements.

In the platinum-silver coils ' $F$ ' and ' $G$ ' appreci- able changes were noted between 1880 and 1908 . These are probably due to the fact that during that period the coils were on several occasions measured at $0^{\circ} \mathrm{C}$. ; strains may have been produced at the soft soldered joints. In recent years, when the coils have been maintained at a temperature not far removed from $16^{\circ} \mathrm{C}$, the changes have been remarkably small.

The main conclusion to be drawn from the series of investigations from 1865 to the present date is that the platinum coils ' $\mathrm{D}$ ' and ' $\mathrm{E}$ ' have retained their value unchanged, while changes have occurred in all the coils made of alloys. These changes are partly due to the violent temperature changes to which all the coils have been subjected at various times.

We may also conclude that pure metals like platinum are usually more stable in their properties than alloys like manganin. Unfortunately, the pure metals suitable for standards have tempera. ture coefficients varying from 0.003 to 0.007 , so measurements would have to be taken at $0^{\circ} \mathrm{C}$., as this is practically the only temperature at which they can be maintained sufficiently constant.

\title{
Obituary
}

Prof. W. Strirling

$\mathrm{W}$ ILLIAM STIRLING, formerly Brackenbury professor of physiology at the University of Manchester, died on October 1. Prior to his going to Manchester he held the regius chair of the Institutes of Medicine at Aberdeen.

Stirling was born at Grangemouth in 1851, received his early education at the Dollar Academy and then became an undergraduate at Edinburgh. Here he had a career of great distinction, graduating as B.Sc. in 1870 and two years later as D.Sc., M.B. and C.M. In his medical final examination he was awarded first class honours. He also gained the Baxter scholarship, the Falconer fellowship and Ettles prize. His thesis in 1875 on "The Summation of Electrical Stimuli applied to the Skin" brought him the M.D. degree and with it the gold medal. After his student career in Edinburgh he worked in Leipzig, Berlin and Paris; and then returned to Edinburgh as demonstrator under Rutherford. His election to the regius chair at Aberdeen shortly after this time and when he was but twenty-six years old, indicates clearly the great promise of his early years and the esteem in which he was held.

After eleven years in Aberdeen, during which time he introduced there the practical teaching of physiology, Stirling was elected as successor to Arthur Gamgee in the chair of physiology at Owens College, Manchester. Here he remained until his retirement in 1919.

Stirling became a professional physiologist at a time when the teaching of physiology in many of the medical schools of Great Britain was inadequate and very little research work was done. In France and Germany, however, the subject in the hands of such masters as Bernard, Helmholz and Ludwig, had developed into an important experimental science. It is not surprising, therefore, that Stirling's sojourn abroad inspired in him a great affection for the men under whom he had studied, and this was apparent from his frequent references to them in his lectures and in private conversation. Carl Ludwig especially was held by him in great regard.

Nevertheless, although in his early post-graduate days Stirling carried out promising research work, he eventually became an interpreter of the work of others rather than an investigator himself. Both at Aberdeen and in Manchester, he introduced elaborate methods of teaching and was largely responsible in the latter school for the extension of the medical building which houses the present physiological laboratories. In addition to his work for his own department at Manchester, Stirling acted as Dean of the Medical School from 1902 until 1913, showing himself to be a capable administrator and devoting himself wholeheartedly to the general welfare of the School. It is probable that these heavy administrative duties coupled with the labours involved in bringing into being the new medical buildings were largely responsible for the attention he devoted to exposition rather than to physiological research. Of his publications, probably the best known are his "Apostles of Physiology", "Outlines of Practical Physiology" and the "Text Book of Physiology" by Landois and Stirling; the last-named being a translation of Landois's book, to which Stirling made many valuable additions.

Stirling was a man who made many friends and did not easily lose them. His fine stature, impres-

No. 3286, Vol. 130] 
sive manner and mode of dress made him a striking figure. Men who were his students still talk of his attractive personality, the great clarity and interest of his lectures and the minute detail with which his practical classes were organised. As a popular lecturer he was in great demand and through this became widely known. This stimulation of interest in biological science in the latter part of last century was probably of great value in gaining support for the scientific departments of the university colleges of the north of England in their earlier days.

In 1904 Stirling received the honorary degree of LL.D. from the University of Glasgow and in 1906 he was Fullerian professor of physiology at the Royal Institution, London.

H. S. R.

\section{Dr. F. H. HATCH}

THE death of Dr. Frederick Henry Hatch on September 22, at sixty-eight years of age, will be regretted by numerous friends in mining and metallurgical circles. Dr. Hatch was born in London, and after studying at University College, proceeded to the University of Bonn, where he took the degree of Ph.D. He spent six years as a member of H.M. Geological Survey, when his work was largely petrological, dealing especially with the igneous rocks of Scotland.

Dr. Hatch recognised, however, that there was a great opportunity for a geologist in the then newly discovered goldfield of the Witwatersrand, and in 1892 he resigned his appointment and went to the Transvaal, where he soon achieved a high reputation as a mining engineer and consulting geologist. $\mathrm{He}$ undertook exploration work of the highest importance for various gold mining interests, his most significant work in Africa being that in connexion with the development of the eastern extension of the Rand goldfield, in the region where the reefs disappear below a great thickness of newer rocks.

In 1895 Dr. Hatch became associated with Cecil Rhodes and John Hayes Hammond in the development of Rhodesia, but the Jameson Raid and the Boer War caused such a general disturbance of this and all his other work that he left Africa for some time, visiting the United States, Canada, British Columbia, and Abyssinia. He also spent a year in India, investigating the gold resources of that country for the Government. His report on the Kolar goldfield may be regarded as a classic in mining literature. At the close of the Boer War he returned to Johannesburg. An intensive boring campaign under his advice finally revealed the structure of the East Rand, which is now the most important producing area, and rendered its development practicable. About 1906 Dr. Hatch left Africa for England, where he established a large practice as a consulting mining engineer, visiting Siberia and other countries. In 1909 he undertook on behalf of the Government an investigation of the mineral resources of Natal.
From 1910 to 1913 Dr. Hatch resided in Cam. bridge, where he lectured on economic geology and presented to the University a very fine collection of specimens of metalliferous ores collected during the course of his professional work. In 1914 he was president of the Institution of Mining and Metallurgy.

After the outbreak of the War, during which he lost his two elder sons, Dr. Hatch was engaged in the Ministry of Munitions and played a prominent part in the organisation of home supplies of iron ores, a piece of work which was of immense service in the organisation of victory. After the War he reported on the condition of the iron and steel works in Lorraine, in the occupied areas of Germany, in Belgium and in France, and then became director of the Mineral Resources Development Branch of the Board of Trade and technical adviser to the Mines Department.

In addition to all this, however, Dr. Hatch was a man of high attainments on the side of pure science. He was the author of books on mineralogy, petrology, and ore deposits which did much to render these subjects intelligible to the average student. The number of editions is evidence of their success and usefuliness. In the last few years petrology has become infinitely and perhaps unnecessarily complicated, but nevertheless many of the existing classifications of rocks bear a strong imprint of the common-sense system of the editions of Hatch's "Petrology" of 1907 and later years.

Str Everard rm Thury, K.c.M.g., K.B.e.

The death of Sir Everard Ferdinand im Thurn, colonial administrator, anthropologist and naturalist, at eighty years of age, took place on October. 8 at his residence, Cockenzie House, Prestonpans. The son of John Conrad im Thurn, merchant-banker, he was educated at Marlborough and at Exeter College, Oxford. Before going to Oxford he had already in 1869 published a book on the birds of Marlborough. In 1877 he went to British Guiana as curator of the museum. He there took up the scientific study of the country and its peoples, being the first to ascend Roraima, and publishing a work on the botanical results of that expedition. In 1882 he was appointed judge in the Pomerun District and in 1890 was made Government Agent in the North-Western District. He joined the staff of the Colonial Office in 1899, having been made C.M.G. in 1892, and was made C.B. in 1900 . $\mathrm{He}$ was appointed Colonial Secretary and Lieutenant-Governor of Ceylon in 1901 and Governor of Fiji and High Commissioner of the Pacific in 1904. In the following year he was promoted to K.C.M.G. and in 1910 he retired. In 1918 he was made a K.B.E. From 1919 until 1921 he was president of the Royal Anthropological Institute, and on taking up his residence in Scotland shortly after he had held that office, he helped to organise and became the first local president of the Edinburgh branch of the Institute. 